\title{
PROMJENE TERMOREGULACIJE U STARIJOJ DOBI
}

\author{
Zijad Durakovićl, Ljerka Ostojić2, Marjeta Mišigoj-Duraković3, \\ Zdenko Ostojić ${ }^{4}$
}

${ }^{1}$ The World Life Institute, Waterport, NY i Washington, DC, SAD i Hrvatsko društvo za gerontologiju i gerijatriju, Zagreb, ${ }^{2}$ Zavod za anatomiju, Medicinski fakultet Sveučilišta u Mostaru, ${ }^{3}$ Zavod za kineziološku antropologiju, Kineziološki fakultet Sveučilišta u Zagrebu, ${ }^{4}$ Klinika za ortopediju, Medicinski fakultet Sveučilišta u Mostaru

Autor za korespondenciju:

Zijad Duraković

dr.zijad.durakovic@gmail.com

primljen: 2019, prihvaćen: 2019, objavljen: 2020.

\section{Apstrakt}

Navedeni su štetni učinci pregrijavanja (hipertermije) i pothlađivanja (hipotermije) u starijoj dobi. Opasnost smrtnog ishoda u pregrijavanju ovisi više o težini pridružene bolesti nego o težini stresa zbog toga stanja. Štetni učinci stresa su lokalna krvarenja, degeneracija stanica parenhimnih organa cijelog tijela, a napose središnjeg živčanog sustava, oštećenje stanica jetre, bubrega i drugih organa. Letalni ishod može se dogoditi i nekoliko dana nakon hipertermije napose u bolesnika koji boluju od šećerne bolesti, kronične opstrukcijske bolesti pluća, bolesti povišena krvnog tlaka u kojih je 50\% viši. Liječenje pregrijavanja treba provoditi u bolničkim uvjetima uz trajno praćenje kliničkih $i$ laboratorijskih parametara. Treba uspostaviti normalnu tjelesnu temperaturu što je prije moguće. Pothlađivanje se može podijeliti u 3 skupine: blago (rektalna temperatura $35-32^{\circ} \mathrm{C}$ ), umjereno (rektalna temperatura $32-28^{\circ} \mathrm{C}$ ); teško (rektalna temperatura niža od $28^{\circ} \mathrm{C}$ ). U tom stanju u starijoj dobi visoka je opasnost letalnog ishoda koji može izgledati kao moždani udar ili kao metaboličke promjene. Oštećenja organizma posebno se događaju u ustrojnim i funkcijskim promjenama malih krvnih žila, stanica, živaca i kože. Neki čimbenici opasnosti za pothlađivanje su smanjenje stvaranja topline, promjene termoregulacije, smanjenje tjelesne aktivnosti. Svako stanje pothlađivanja, pa i blago, treba liječiti u Jedinici intenzivnog liječenja, dok se ne uspostavi potpuni oporavak. Dva su puta u liječenju: primarno je liječenje utopljavanjem, a sekundarno je liječenje komplikacija. Cilj liječenja je sporo povisivanje rektalne temperature, ne brže od $0,6^{\circ} \mathrm{C}$ na sat. U teškom pothlađivanju postupci reanimacije trebaju biti agresivni i produženi. Ne treba proglasiti smrtni ishod dok se ne ustanovi da je kardio-pulmonalno-cerebralna resuscitacija neučinkovita, no tek nakon što se povisi rektalna tjelesna temperatura na najmanje $35,8^{\circ} \mathrm{C}$.

Ključne riječi: starija dob, pregrijavanje, pothlađivanje. 


\section{Uvod}

Pregrijavanje (tjelesna temperatura viša od $\left.37,5-38,3^{\circ} \mathrm{C}\right)(1-4)$, kao i pothlađivanje (tjelesna temperatura niža od $35^{\circ} \mathrm{C}$ ) mogu biti problem u medicini starije dobi (5-12). Tjelesna temperatura regulirana je iz preoptičke regije prednjeg dijela hipotalamusa, gdje je mnogo stanica koje su osjetljive na promjene temperature tijela. Tu je tri puta manje stanica koje su osjetljive na hladnoću nego onih osjetljivih na povišenu temperaturu. Osim hipotalamusa, tjelesnu temperaturu reguliraju receptori u drugim dijelovima tijela. Termoreceptori u koži i duboki receptori koji se nalaze u kralježničkoj moždini, trbušnim organima, velikim venama gornjeg dijela trbuha i prsišta, deset puta su osjetljiviji na hladnoću nego na toplinu. Time se organizam brani od pothlađivanja (1-12).

Senzorni signali za toplinu nalaze se u perifernim receptorima, no u te je procese dominantno uključen hipotalamus. Ti signali stimuliraju obje strane stražnjeg dijela hipotalamusa. Senzorni signali za toplinu koji se nalaze u preoptičkom području prednjeg dijela hipotalamusa usmjeravaju se k stražnjem dijelu i integriraju informacije od preoptičkog područja i perifernih dijelova, s posljedičnim stvaranjem i održavanjem topline. Pri tome su značajni temperaturni senzori: tako npr. povisivanje tjelesne temperature za $10^{\circ} \mathrm{C}$ dovodi do ubrzanja impulsa topline za $2-10$ puta $(1-4)$. Sniženje tjelesne temperature dovodi do povećanja aktivnosti živčanih stanica koje su osjetljive na hladnoću.

U snižavanju povišene tjelesne temperature sudjeluje nekoliko živčanih efektornih mehanizama: 1) širenje krvnih žila u koži mehanizmom inhibicije simpatičkog područja u stražnjem dijelu hipotalamusa; 2) znojenje: porast tjelesne temperature za $1{ }^{\circ} \mathrm{C}$ dovodi do $10 \mathrm{x}$ više topline nego što je to u bazalnim uvjetima; 3) sniženje proizvodnje topline: znojenje i kemijska termogeneza se zaustavljaju. U promjenama termoregulacije tijela, povišena tjelesna temperatura može rezultirati promjenama središnjeg živčanog sustava i toksičnim učinkom na centar za termoregulaciju. Neki razlozi tome mogu biti bakterijska infekcija, tumori središnjeg živčanog sustava, kao i čimbenici okoline kao npr. toplinski udar (1-3).

\section{Regulacija tjelesne temperature u starijoj dobi}

U normalnim uvjetima odavanje topline konvekcijom i "isijavanjem" (radijacijom) reda je veličine gubitka tjelesne topline od oko 65\%. Gubitak topline znojenjem i plućima označava dodatnih 30\%. Hipotalamus regulira gubitak 
topline putom neuroendokrinih i autonomnih mehanizama. Povišena temperatura dovodi do širenja krvnih žila, a kolinergički učinci dovode do znojenja. Širenje krvnih žila refleksno dovodi do porasta frekvencije i minutnog volumena srca. Kada temperatura okoline dosegne temperaturu tijela, toplina se više ne može gubiti konvekcijom i radijacijom. Tu preostaje još jedini mehanizam za gubitak topline: evaporacija (hlapljenje), no porast vlažnosti u zraku priječi taj mehanizam hlađenja. Sa starenjem se smanjuje učinkovitost znojenja u procesu hlađenja organizma. To je napose značajno u stanjima u kojima pirogene tvari mogu biti bjelančevine, njihovi dijelovi, kao i toksini od lipofilnih polisaharida bakterijskih staničnih membrana. Visoka tjelesna temperatura može biti posljedica endotoksina Gram negativnih bakterija, leukocita iz krvi, tkivnih makrofaga, granularnih limfocita koji fagocitiraju bakterije, kao i oslobođenih citokina iz tjelesnih tekućina, a napose interleukina 1(IL-1), koji je endogena leukocitna pirogena tvar koju proizvodi hipotalamus, a što stimulira proces utopljavanja u vremenu unutar 8-10 min.

\section{Termogeneza u pregrijavanju}

Povišena tjelesna temperatura dovodi do pogoršavanja nekih kroničnih bolesti. Pregrijavanje dovodi do mnogih patofizioloških promjena: smrtnost u starijih osoba progresivno se povećava za vrijeme vrućeg i vlažnog vremena (oko $80 \%$ u dobi iznad 50 godina). U bolesnika koji boluju od šećerne bolesti, kronične opstrukcijske bolesti pluća ili bolesti povišenog krvnog tlaka, tijekom vrućeg vremena smrtnost iznosi više od 50\%. Opasnost od smrtnog ishoda zbog pregrijavanja tijela više ovisi o težini pridruženih bolesti nego o jačini hipertermije. Štetni učinci pregrijavanja su lokalna krvarenja, degeneracije stanica parenhimnih organa cijelog tijela, a napose središnjeg živčanog sustava, oštećenja jetre, bubrega, kao i drugih parenhimnih organa, a smrtni ishod može se dogoditi čak i nekoliko dana nakon hipertermije. U bolesnika koji boluju od bolesti srca visoka je opasnost komplikacija pregrijavanja. U laboratorijskim uvjetima, visoka temperatura i visoka vlažnost okoline povećava opasnost zatajivanja crpne funkcije srca. Što je veće zahvaćanje kardiovaskularnog sustava tim stanjem, to su manji izgledi da će sam organizam kompenzirati novo stanje (1-12).

Zbog pregrijavanja u starijoj dobi, mnoge endokrine žlijezde postaju promijenjene fibroznim tkivom i funkcija im se smanjuje. Vezivno tkivo postaje manje vaskularno. Žlijezde znojnice u uvjetima visoke temperature okoline stvaraju manje znoja. Događaju se mišićni grčevi zbog profuznog znojenja 
i polidipsije, a bez bitnog porasta temperature tijela, kao posljedica gubitka tekućine i elektrolita, kada se oni obično nadoknađuju samo vodom. No potrebna je nadoknada elektrolita, koja priječi mišićne grčeve.

Karakteristike iscrpljenosti organizma pregrijavanjem mogu biti: gubitak teka, mučnina, povraćanje, neorijentiranost, sniženi krvni tlak u uspravnom položaju tijela. Mogu se pojaviti mišićni grčevi, pri čemu tjelesna temperatura može biti normalna ili povišena. Ti bolesnici tuže se na žeđ, opću slabost, a pokazuju i smetnje središnjeg živčanog sustava: glavobolju, vrtoglavicu, gubitak svijesti. Dva su osnovna znaka iscrpljenosti vrućinom. Gubitak tjelesne vode dovodi do hipertonične dehidratacije. Gubitak soli ima za posljedicu grčeve, jer se voda i $\mathrm{NaCl}$ gube znojenjem. Takvu bolesniku treba nadoknaditi vodu i elektrolite intravenskim putom. Velike komplikacije kao i letalni ishod u tom su stanju rijetki.

Nemogućnost gubitka topline u starijoj dobi nosi opasnost porasta temperature zbog izostanka znojenja, što ima za posljedicu promjene središnjeg živčanog sustava. Čimbenici opasnosti 12 su puta češći u osoba biološke dobi iznad 65 godina nego u mlađoj dobi. Opasnost se povećava u alkoholičara, u onih osoba koje se ne mogu same za sebe brinuti i pomoći si, u bolesnika koji boluju od duševnih bolesti, tamo gdje ne postoji mogućnost uključivanja izmjenjivača zraka (tzv. klimatizirani sustavi), u onih koji boluju od pridruženih bolesti kao npr. kardiovaskularnih, cerebrovaskularnih, šećerne bolesti, kronične opstrukcijske bolesti pluća (1-4).

Znaci toplinskog udara u starijoj dobi mogu biti u oblasti tzv. hipodinamičnog stanja kardiovaskularnog sustava. Hiperdinamično stanje u osoba mlađe dobi uključuje ubrzan rad srca frekvencije 160-180/min., normalan ili povišeni minutni volumen srca, krvni tlak u granici normale, povišen središnji venski tlak. Hipodinamično stanje u osoba starije dobi ima sljedeće znakove: usporenu frekvenciju srca, snižen ili teško mjerljiv krvni tlak, hipovolemiju, normalni plućni kapilarni tlak. U tom hipodinamičnom stanju zbiva se nemogućnost adaptacije organizma na stres zbog toplinskog udara, nemogućnost adekvatnog porasta frekvencije srca, kao i nemogućnost adaptacije perifernog krvožilnog otpora. Zbog tih razloga dijagnoza tog stanja postavlja se kasnije, s rezultirajućim velikim gubitkom tekućine.

Znakovi toplinskog udara u osobe starije dobi uključuju promjene središnjeg živčanog sustava: pospanost, letargiju (stupor) i komatozno stanje. Zapis elektroencefalograma u početku ne ukazuje na promjene ako nema napadaja grčeva (epileptički), a nema bitnih promjena ni u nalazu cerebrospinalnog likvora. No neurološki deficit (oduzetost i sl.) ostaju u oko 5\% onih koji se 
uspješno oporave od toplinskog udara. U onih koji ne prežive to stanje, obdukcijski nalaz upućuje na edem mozga, kao i na difuzna petehijska krvarenja.

Znaci toplinskog udara u bolesnika starije dobi koji boluju od bolesti bubrega mogu biti od blaže proteinurije do akutnog zatajenja bubrega (u 10$30 \%$ ), rabdomioliza, metabolička acidoza s visokom koncentracijom laktata i s kompenzatornom respiratornom alkalozom, teška hipokalemija, koja je sekundarna zbog porasta sekrecije aldosterona. Oštećenja jetre rijetko se događaju, a mogu biti praćena porastom serumske koncentracije aspartat transaminaze (AST) i alanin transaminaze (ALT), ponekad uz ikterus $(1,2,4)$. Promjene koagulacije krvi mogu se sastojati u porastu protrombinskog vremena i aktiviranog parcijalnog tromboplastinskog vremena (APTV), kao i snižavanja koncentracije serumskog fibrinogena. Rijetko se zbiva diseminirana intravaskularna koagulacija krvi.

Simptomi i znaci pregrijavanja u starijoj dobi mogu biti: tjelesna temperatura viša od $41^{\circ} \mathrm{C}$ (no može biti i niža od te vrijednosti), nedostatak znojenja, teške promjene funkcije središnjeg živčanog sustava. Prodromalni simptomi mogu biti prolazni: laka do intenzivna glavobolja, vrtoglavica, opća slabost, otežano disanje, mučnina, no prvi znak može biti gubitak svijesti.

Liječenje pregrijavanja u osoba starije dobi treba se žurno provoditi $\mathrm{u}$ bolničkim uvjetima uz kontinuirano praćenje svih potrebnih kliničkih i laboratorijskih parametara. Treba uspostaviti normalnu tjelesnu temperaturu čim je prije moguće. Bolesnika treba hladiti u kupki s hladnom vodom dok mu se tjelesna temperatura ne snizi na $38,8^{\circ} \mathrm{C}$ - tu ne treba pretjerati kako se ne bi dogodila hipotermija, pa dalje snižavanje tjelesne temperature treba provoditi mokrom spužvom. Središnji venski tlak ili plućni kapilarni tlak treba trajno mjeriti i ocjenjivati potrebu za nadoknadom tekućine. Treba kontrolirati parametre funkcije bubrega i metaboličke promjene, a bakterijsku infekciju liječiti u začetku (1-4).

Opasnost toplinskog udara u starijoj je dobi visoka. Priječenje pregrijanosti tih osoba sastoji se u prozračivanju prostorija za vrijeme visoke temperature okoline, makar i kratkotrajno uključivanje klima-uređaja u prostoriji u kojoj ta osoba boravi, no ako to nije moguće, treba koristiti ventilator. Odjeća treba biti lagana, prozori noću otvoreni, treba uzimati dovoljno tekućine, kao i izbjegavati tjelesne napore. Treba skrenuti pozornost i okolini starijeg bolesnika na činjenicu kako kliničko ispoljavanje pregrijavanja može biti praćeno posve nespecifičnim tegobama.

Neki lijekovi mogu dovesti do smanjivanja znojenja tijela i povećati sklonost $\mathrm{k}$ pregrijavanju pa ih treba izbjegavati ili im smanjiti dozu: npr. neki 
antikolinergici, antihistaminici, antiparkinsonici, antipsihotici, butirofenoni, fenotijazini, antidepresivi, MAO inhibitori, triciklički antidepresivi. Zbog pregrijavanja treba izbjegavati i diuretike koji mogu dovesti do daljeg gubitka tekućine, hipovolemije i njenih komplikacija (1-4).

\section{Pothlađivanje}

Neuralni efektorni mehanizmi za priječenje sniženja tjelesne temperature su: 1) vazokonstrikcija kože i cijelog tijela zbog stimulacije simpatičke regije stražnjeg dijela hipotalamusa; 2) piloerekcija (manje značajan mehanizam); 3) povećanje proizvodnje topline organizma: a) drhtanjem, b) aktivacijom simpatikusa, c) proizvodnjom tiroksina.

Pothlađenost se događa kada rektalna temperatura iznosi niže od $35^{\circ} \mathrm{C}$. Može se podijeliti u 3 skupine: blago pothlađivanje (rektalna temperatura $35-32^{\circ} \mathrm{C}$ sa stopom smrtnosti oko $35 \%$ ), umjereno pothlađivanje (rektalna temperatura $32-28^{\circ} \mathrm{C}$ sa stopom smrtnosti $60-80 \%$ ), teško pothlađivanje (rektalna temperatura $<28^{\circ} \mathrm{C}$ sa stopom smrtnosti 90-100\%).

Pothlađenost u starijoj dobi znači nemogućnost održavanja normalne tjelesne temperature. Hladan vjetar, neadekvatna odjeća i obuća, uzimanje nekih sredstava koja mogu dovesti do hipotermije, opća slabost, mogu dovesti do pothlađenosti opasne za život, pa čak i u uvjetima temperature okoline koja nije niža od $10-15^{\circ} \mathrm{C}$. Kad drhtanje prestane, tijelo više nije u mogućnosti zadržavati toplinu i temperatura mu se snižava (12-14).

Patofizološke posljedice pothlađenosti su sljedeće: stvaraju se kristali leda između stanica, koji ometaju funkciju natrijeve crpke, puca stanična stijenka, stvaraju se konglomerati eritrocita, agregacija trombocita dovodi do stvaranja tromboza, neurovaskularni impulsi skreću tokove krvi. Opći metabolički učinci pothlađenosti imaju za posljedicu hipoksiju i nekroze tkiva (11-16).

Komplikacije u onih koji su preživjeli mogu biti: kardiogeni edem pluća, upala pluća, akutna upala gušterače, pogoršanje šećerne bolesti, metabolička acidoza, akutno zatajenje bubrega, gangrene udova. Kada je cijelo tijelo izloženo niskoj temperaturi okoline, aktiviraju se refleksi kako bi se povisila tjelesna temperatura: drhtanjem, zaustavljanjem perspiracije, vazokonstrikcijom u koži. 


\section{Termogeneza u pothlađivanju}

Podražaj za drhtanje tijela događa se u hipotalamusu, što uključuje motorički centar za drhtanje u dorzomedijanom stražnjem dijelu hipotalamusa blizu stijenke 3. komore. To je podraženo impulsima receptora za hladnoću koji se nalaze u koži i leđnoj moždini. Impulsi koji dovode do drhtanja idu iz centara duž cerebralnog trunkusa do lateralnih rogova leđne moždine i potom do prednjih motoneurona.

U pothlađenosti se povećava proizvodnja tiroksina. Tireoidni oslobađajući hormon (TRH) proizvodi se u prednjem dijelu hipotalamusa, dolazi do hipofize pomoću hipotalamične portalne vene i podražuje njen prednji dio na proizvodnju tiroidnog stimulirajućeg hormona (TSH), koji stimulira proizvodnju tiroksina za stimulaciju metabolizma cijelog tijela. To je mogući razlog porasta učestalosti toksične nodularne gušavosti u osoba koje žive u hladnim klimatskim uvjetima, jer hladnoća trajno stimulira štitnu žlijezdu. U stimulaciji simpatikusa, adrenalin i noradrenalin povisuju tjelesnu temperaturu djelujući na oksidativnu fosforilaciju, čime se tjelesna temperatura u osoba odrasle dobi povisuje za $10-15 \%$.

Karakteristike akcidentalne pothlađenosti u starijoj su dobi neočekivano sniženje tjelesne temperature na niže od $35^{\circ} \mathrm{C}$ (rektalna temperatura), što je uobičajeno u zimskom vremenu. Visoka opasnost tog potencijalno letalnog stanja leži u činjenici sličnosti s moždanim udarom ili metaboličkim promjenama. Loše grijane prostorije u zimskom vremenu i izlaganje hladnoći u boravku osoba starije dobi, čija je temperatura okoline niža od $18^{\circ} \mathrm{C}$ (dakle, to se ne odnosi samo na zimsko vrijeme) tijekom više sati ili više dana, može imati za posljedicu pothlađenost. Oštećenja organizma imaju za posljedicu ustrojne i funkcijske promjene malih krvnih žila, stanica, živaca i kože hladnoćom (12-16).

Izlaganje vlažnoj hladnoći (kada je temperatura okoline blizu točke smrzavanja) može imati za posljedicu stvaranje ranih ozeblina nogu. Izlaganje suhoj hladnoći (kada je temperatura okoline blizu točke smrzavanja) može imati za posljedicu ozebline nogu i akcidentalnu hipotermiju. Gubitak tjelesne topline može se dogoditi kondukcijom, npr. zbog vlažne odjeće, kontaktom s metalnom površinom, ali i konvekcijom, npr. zbog izlaganja hladnom vjetru ili zračenjem (12-14).

Starije osobe sklonije su oštećenjima organizma hladnoćom zbog dehidratacije, uzimanja alkoholnih pića (vazodilatacija), promjene svijesti, iscrpljenja, gladi, malokrvnosti, bolesti cirkulacije krvi, bolesti srca i krvnih 
žila, vazokonstrikcije, policitemije. Neki čimbenici opasnosti pothlađivanja u starijoj dobi mogu biti smanjena proizvodnja topline tijela, oštećeni procesi termoregulacije, imobilizacija - smanjenje tjelesne aktivnosti. Smanjenje proizvodnje tjelesne topline može se dogoditi tijekom dijabetičke ketoacidoze, hipoglikemije, hipopituitarizma, malnutricije, gladovanja, hipotireozemiksedema. Oštećena termoregulacija može se dogoditi tijekom dijabetičke ili alkoholne polineuropatije, primarne bolesti središnjeg živčanog sustava, traume glave, poliomijelitisa, moždane kapi, subarahnoidnog krvarenja, subduralnog hematoma, tumora, Wernickeove encefalopatije, sustavnih bolesti koje zahvaćaju i hipotalamus, otrovanja ugljik-monoksidom, uremije. Razlozi za smanjenu tjelesnu aktivnost u starijoj dobi mogu biti Parkinsonova bolest, artritis, demencija (napose Alzheimerova bolest), padovi i druge ozljede, paraliza, moždana kap (12-14).

Gubitak tjelesne topline, osim zbog vlažne odjeće, može biti i zbog kontakta s metalnom površinom, konvekcijom zbog hladna vjetra, radijacijom. Ukupna smrtnost od pothlađenosti u starijoj dobi iznosi oko 50\%. Pothlađeni bolesnici biološke dobi iznad 75 godina imaju pet puta viši izgled letalnog ishoda nego oni dobi niže od te dobi. Smrtnost u tih osoba jače je vezana za nazočnost i težinu pridružene bolesti nego za stupanj pothlađenosti. Stariji bolesnici koji boluju od šećerne bolesti imaju 6 puta višu opasnost hipotermije, vjerojatno zbog promjena krvnih žila koje loše utječu na mehanizam regulacije tjelesne topline. U akcidentalnom pothlađivanju osoba starije dobi događa se nekonstriktorni vazomotorni odgovor na hladnoću, čija je posljedica snižen krvni tlak u stajanju. Sniženje temperature ispod $35^{\circ} \mathrm{C}$ opaža se zimi u oko 3,5\% osoba starije dobi. Stoga treba imati na umu kako pothlađenost može sličiti na moždani udar ili promjene metabolizma $(5,12,13)$.

Lijekovi koji u starijoj dobi povećavaju sklonost k pothlađivanju su: antidepresivi, barbiturati, benzodijazepini, opioidi, fenotijazini, uzimanje alkoholnih pića. Predisponirajući čimbenici za pothlađivanje su zatajivanje crpne funkcije srca, hipotireoza, hipopituitarizam, kronično zatajivanje funkcije bubrega, Addisonova bolest, gladovanje, ketoacidoza (npr. dijabetička), plućne infekcije, sepsa, moždana oštećenja, kao i bolesti koje su praćenje imobilizacijom. U starijoj dobi sklonost k oštećenju organizma hladnoćom povećava se s dehidratacijom, uzimanjem alkoholnih pića, promjenama svijesti npr. kao posljedica moždane kapi, iscrpljenosti, gladi, malokrvnosti, anemijom, promjenama cirkulacije krvi zbog kardiovaskularnih bolesti, sužavanju krvnih žila, Vaquez-Oslerovom bolesti (polycythemia rubra vera). 
Simptomi i klinički znaci pothlađivanja mogu biti: umor, opća slabost, nekoordinacija, bezvoljnost, konfuzno stanje, pospanost, halucinacije, agresivnost, neprihvaćanje pomoći, akutna stanja konfuzije, napose kada je rektalna tjelesna temperatura niža od $32^{\circ} \mathrm{C}$, što sve progredira do stupora i komatoznog stanja (5-16). Teško pothlađenog bolesnika treba liječiti u bolničkim uvjetima. Čak i umjerena hipotermija predstavlja stanje žurnosti i treba je liječiti u bolničkim uvjetima, sve dok se ne dogodi potpuni oporavak. Dva su osnovna zadatka zbrinjavanja takvog bolesnika: primarni je utopljavanje, a sekundarni je liječenje komplikacija. Utopljavanje se provodi pokrivanjem tijela sintetskim dekama u toploj prostoriji, sve do primjene ugrijane infuzijske otopine na $37^{\circ} \mathrm{C}$, pa i peritonealne hemodijalize pomoću ugrijane otopine. Cilj je sporo utopljavanje, ne brže od $0,6^{\circ} \mathrm{C} / \mathrm{h}$, dok se rektalna temperatura tijela ne dovede u normalne granice. Kada bi se utopljavanje brže provelo, posljedica bi mogla biti ireverzibilno sniženje krvnog tlaka, pojava nove aritmije srca, kao i pogoršanje metaboličke acidoze. U bolesnika koji su u dubokoj hipotermiji, postupci resuscitacije za vrijeme utopljavanja trebaju biti agresivni i prolongirani. Bolesnik ne smije biti proglašen mrtvim sve dok tjelesna temperatura nije dovedena u normalne granice, a i dalje su odsutni vitalni znaci.

\section{Zaključci}

Opasnost od smrtnog ishoda tijekom hipertermije u osoba starije dobi može ovisiti više o pridruženim bolestima nego o intenzivnosti toplinskog udara. Štetni učinci mogu biti lokalna krvarenja, degeneracije stanica parenhimnih organa cijelog tijela, a napose središnjeg živčanog sustava, oštećenja jetre, bubrega, kao i drugih parenhimnih organa. Smrtni ishod može se dogoditi i nekoliko dana nakon hipertermije. Liječenje pregrijavanja osoba starije dobi predstavlja medicinsku žurnost, bolničko liječenje i trajno praćenje zdravstvenog stanja.

U pothlađivanju u osoba starije dobi, visoka je opasnost za razvoj potencijalnih smrtnih događaja, a mogu sličiti razvoju moždane kapi, kao i metaboličkim promjenama. Oštećenja organizma pothlađivanjem dovode do funkcijskih i ustrojnih promjena malih krvnih žila, stanica, živaca i kože. Bolesnik koji boluje čak i od blaže hipotermije treba biti liječen u Jedinici intenzivnog liječenja sve dok se potpuno ne izliječi. Dva su osnovna cilja liječenja tog stanja: primarno liječenje utopljavanjem i sekundarno liječenje komplikacija. Cilj je sporo, postupno utopljavanje brzinom koja ne smije biti veća od $0,6^{\circ} \mathrm{C}$ na sat, dok se rektalna tjelesna temperatura ne povisi do normalne granice. 


\section{Reference}

1. Brody GM. Hyperthermia and hypothermia in the elderly. Clin Geriatric Med. 1994;10(1):213-29.

2. Young AJ, Lee DT. Aging and human cold temperature. 1995. https://doi. org/10.01080/03610739708254026.

3. Sawatari H, Chishaki A, Miyazono M, Hashiguchi N, Maeno Y, Chishaki H, et al. Different physiological and subjective responses to the hyperthermia between young and older adults: Basic study for thermal therapy in cardiovascular diseases. J Gerontol. 2015;70(7):912-6. https://doi.org/10.1093/gerona/glu224.

4. Kenny GP, Poirier MP, Metsios GS, Boulay P, Dervis S, Fiesen BJ, et al. Hyperthermia and cardiovascular strain during an extreme heat exposure in young versus older adults. $\mathrm{J}$ Temp. 2017;4(1):79-88.

5. Duraković Z, Mišigoj Duraković M, Čorović N. Hypothermia and acute renal failure in the elderly. Coll Antropol. 1998;22:135-40.

6. Duraković Z. Funkcijske i somatske promjene u organizmu starije osobe. Medix 2000;29:23-7.

7. Duraković Z. Hipersaturacija i otrovanje lijekovima u starijoj dobi. Medicus. 2005;14:26172.

8. Duraković Z. Hipotermija. U: Duraković Z i suradnici. Gerijatrija - Medicina starije dobi. Zagreb: CT-poslovne informacije, 2007. str. 296-8.

9. Duraković Z, Žarković N. Biologija starenja i gerijatrija. U: Vrhovac B i suradnici. Interna medicina, 4. izdanje. Zagreb: Naklada Ljevak, 2008. str. 69-77.

10. Duraković Z. i suradnici. Farmakoterapija u gerijatriji - Geriatric Pharmacotherapy. Zagreb: CT-poslovne informacije, 2011.

11. Duraković Z. Lijekovi u starijoj dobi. U: Francetić I i suradnici. Farmakoterapijski priručnik, 7. izdanje. Zagreb: Medicinska naklada, 2015. str. 26-34.

12. Guly H. History of accidental hypothermia. Resuscitation. 2011;82(1):122-5.

13. Fox RH, Fry AJ, Woodward PM, Collins JC, Macdonald IC. Diagnosis of accidental hypothermia in the elderly. Lancet. 1971;297(7696):424-7.

14. McCullough L, Arora S. Diagnosis and treatment of hypothermia. Am Fam Phys. 2004;70(12):2325-32.

15. Paal P, Rauch S. Indoor accidental hypothermia in the elderly: an emerging lethal entity in the 21-th century. Emerg Med J. 2018;35(11). http://dx.doi.org/10.1136/ emermed-2018-207804.

16. Matsuyama T, Morita S, Ehara N, Miyamae N, Okada Y, Jo T, et al. Characteristics and outcomes of accidental hypothermia in Japan. Emerg Med J. 2018;35:659-66. 


\title{
CHANGES OF THERMOREGULATION IN THE ELDERLY
}

\begin{abstract}
The paper deals with the harmful effects of hyperthermia and hypothermia in the elderly. The risk of hyperthermia-related death may depend more on severity of associated diseases, than on severity of a heat stress. Harmful effects of hyperthermia are local haemorrhage, parenchymal cells degeneration of a whole body, especially central nervous system cells, damage of the liver, the kidneys, and other parenchymal organs, and death event could happen even a few days after heatstroke. Heart diseases increase the risk of heat stress. In increased heat atmosphere, death attributed to diabetes mellitus, chronic obstructive pulmonary diseases, arterial hypertension reach over $50 \%$. Heat stroke in the elderly is a medical emergency and treatment requires hospitalization and continuous monitoring. Normal body temperature should be restored as soon as possible. Hypothermia could be divided in three categories: mild hypothermia (rectal temperature $35-32^{\circ} \mathrm{C}$ ), moderate hypothermia (rectal temperature $32-28^{\circ} \mathrm{C}$ ); severe hypothermia (rectal temperature below $28^{\circ} \mathrm{C}$ ). In hypothermia in the elderly, there is high risk for potential lethal clinical syndrome mimicking stroke and metabolic derangement. Injuries caused by cold can cause structural and functional disturbances of small blood vessels, cells, nerves and skin. Some risk factors for hypothermia could be decreased heat production, impaired thermoregulation, and diminished activity. Hypothermia, even mild, should be treated in an Intensive Care Unit, until complete recovery. There are two foci of the treatment: primary treatment by warming and secondary treatment of direct complications. The goal is slow rewarming, gradually allowing body temp. to return to normal values, but not faster than $0.6^{\circ} \mathrm{C} / \mathrm{h}$. In severe hypothermia, resuscitation should be aggressive and prolonged. Patients should not be pronounced dead until cardio-pulmonary-cerebral resuscitation (CPCR) is shown to be ineffective after body temperature has been raised to at least $35.8^{\circ} \mathrm{C}$.
\end{abstract}

Keywords: elderly, hyperthermia, hypothermia. 